University of Nebraska - Lincoln

DigitalCommons@University of Nebraska - Lincoln

6-2009

\title{
The Continuing Relevance of Family Income for Religious \\ Participation: U.S. White Catholic Church Attendance in the Late 20th Century
}

\author{
Philip Schwadel \\ University of Nebraska-Lincoln, pschwadel2@unl.edu \\ John D. McCarthy \\ Pennsylvania State University \\ Hart M. Nelsen \\ Pennsylvania State University
}

Follow this and additional works at: https://digitalcommons.unl.edu/sociologyfacpub

Part of the Sociology Commons

Schwadel, Philip; McCarthy, John D.; and Nelsen, Hart M., "The Continuing Relevance of Family Income for Religious Participation: U.S. White Catholic Church Attendance in the Late 20th Century" (2009).

Sociology Department, Faculty Publications. 80.

https://digitalcommons.unl.edu/sociologyfacpub/80

This Article is brought to you for free and open access by the Sociology, Department of at DigitalCommons@University of Nebraska - Lincoln. It has been accepted for inclusion in Sociology Department, Faculty Publications by an authorized administrator of DigitalCommons@University of Nebraska - Lincoln. 


\section{The Continuing Relevance of Family Income for Religious Participation: U.S. White Catholic Church Attendance in the Late $20^{\text {th }}$ Century}

Philip Schwadel, University of Nebraska-Lincoln

John D. McCarthy, Pennsylvania State University

Hart M. Nelsen, Pennsylvania State University

The relevance of family income for religious participation in the United States has been largely ignored in recent decades. Addressing this neglect, we focus our attention primarily upon white Catholics, the poorer of whom we reason have fewer options to participate in the context of an increasingly middleclass Church. Analyzing the 1972-2006 cumulative General Social Survey data, we show that net of all other factors lowincome white Catholics attend church less often than other white Catholics, although social integration mechanisms significantly moderate the effects of income. Additional analyses suggest that the effects of income on church attendance are greatest for the younger white Catholic cohort. In contrast, the role of income in Latino Catholics' attendance is relatively weak. In our conclusion, we attempt to integrate our most puzzling finding - having children in the home does not increase the church attendance of low-income white Catholics - with our main theoretical line of argument concerning the central role of social integration in understanding the impact of income on religious participation.

Sociological interest in the relationship between social class and religion has its origins in the writings of Karl Marx, who saw religion as an opiate for the masses, and Max Weber, who wrote of three class-based systems of religious meaning. Of special importance in the American context was the emphasis placed upon social class by H. Richard Niebuhr (1929:19) who wrote of "the churches of the disinherited" or churches that catered to the religious tastes of low-income Americans. Empirical research relying on evidence from the middle decades of the $20^{\text {th }}$ century confirmed differences in the religious activities of lower-class, middle-class and upper-class Christians in the United States, particularly the lack of church

The authors would like to thank Roger Finke, Glenn Firebaugh, Susan Crawford Sullivan, the editor of Social Forces, and three anonymous reviewers for their advice on earlier versions of this article. Direct correspondence to Philip Schwadel, 740 Oldfather Hall, Department of Sociology, University of Nebraska-Lincoln, P.O. Box 880324, Lincoln, NE 68588-0324.E-mail:pschwadel2@unl.edu. 
participation among low-income Christians (e.g., Demerath 1965; Vidich and Bensman 1958). By the 1970s, however, social scientists had come to believe that the effect of social class on religious participation had pretty much disappeared (e.g., Alston and McIntosh 1979; Hoge and Carroll 1978), leading Mueller and Johnson (1975:798) to conclude that the interest in class differences in religious involvement was "perhaps unwarranted (at least in contemporary society)." Subsequently, little attention has been paid to the connection between income and church attendance during the past three decades (for exceptions see Lipford and Tollison 2003; McCloud 2007). The evidence we present here strongly suggests that dismissing the impact of family income on American religious participation may have been premature.

Those who dismissed the role of family income on religious participation worked with evidence largely drawn from Protestants. The more insular nature of American Catholicism, however, may provide a context where income can have a greater impact on Catholics' church attendance than on Protestants' church attendance. Half a century ago, Herberg (1960:221) contrasted the "inner cohesiveness of the Catholic community" with the mobility that is characteristic of American Protestantism. More recently, Sandomirsky and Wilson (1990:1216) note, "The barriers around some denominations, such as the Catholics and the Jews, are higher than those around most Protestant denominations." The "weak and inconsistent" results of empirical research examining social class and religious participation may result from the wide variety of Protestant denominations in the United States and the associated higher rates of Protestant interdenominational mobility (Stark and Finke 2000:32). Meaningful class distinctions among Protestant denominations can provide relatively more class-distinct religious communities for American Protestants (McCloud 2007; Pyle 2006; Smith and Faris 2005). Regardless of changes in the social class composition of specific denominations, at the aggregate there continue to be Protestant denominations that appeal to each segment of the social class continuum (Finke and Stark 1992; Niebuhr 1929; Stark and Finke 2000). In contrast to low-income Protestants who sometimes switch denominations when their church experiences upward mobility, Catholics are quite a bit less likely to switch to another Christian tradition (Sandomirsky and Wilson 1990; Sherkat and Wilson 1995). ${ }^{1}$ Thus, when low-income Catholics are not happy for one reason or another with the atmosphere of their local parish, they may be more likely to reduce their participation or stop attending altogether.

In this article, we ask how the changing social class and ethnic composition of the U.S. Catholic Church affects low-income Catholics' church attendance. Although the Catholic Church in the United States was historically home to poor immigrants and minorities, today many Catholics 
are well educated and belong to the middle and upper classes (Davidson and Williams 1997; Pyle 2006; Smith and Faris 2005). Non-Latino, white Catholics in particular experienced high levels of wealth accumulation in recent decades (Keister 2007). This upward mobility is evident in the changing composition of Catholic schools - about half of U.S. Catholic school students now come from the top one-quarter of the income distribution (Baker and Riordan 1998). Churches that experience upward mobility, such as the Catholic Church, may also experience increasing internal conflict related to class disparities. Finke and Stark (1992:43) observe that "an organization filled with members or leaders who have unrestricted access to the 'enchantments of this world' is severely handicapped in its capacity to serve the religious needs of the less successful." Low-income Catholics may not be comfortable with the rising social status of the average parishioner (McGavran 1980), and a predominantly middle-class parish is hampered in its ability to meet the religious needs of low-income Catholics (Weissbourd 2000). In sum, the social atmosphere of many parishes may no longer be inviting to low-income Catholics.

Relatively high levels of social status diversity in most Catholic churches mean poorer Catholics usually attend church with higher income Catholics. Although religious congregations are largely racially homogeneous, they are relatively heterogeneous when it comes to income (Dougherty 2003; Schwadel 2005). Moreover, Catholic parishes appear to be particularly income diverse (Schwadel 2005). Thus, most low-income Catholics who want to attend a Catholic church must share the pews with middle- and high-income Catholics.

The upward social mobility of large numbers of American Catholics is particularly pertinent to low-income, non-Latino white Catholics' church attendance rates, but this is less so for Latino Catholics. More than twothirds of Latinos in the U.S. affiliate with the Catholic religion and Latinos now account for about one-third of all U.S. Catholics (Suro et al. 2007). Just as "national" parishes served the religious needs of poor Irish, Italian, and Polish immigrants in the first half of the $20^{\text {th }}$ century (Orsi 1985; Shaw 1991), many "ethnic parishes" now cater to low-income Latino immigrants (Levitt 1998; Odem 2004). Ethnic parishes provide relatively homogeneous contexts for minority Catholics; and high levels of church attendance are often the norm in contexts of racial/ethnic homogeneity (Ellison 1995). Given the social and cultural benefits available to Latinos in church, income should have relatively little effect on most Latino Catholics' church attendance.

We emphasize the moderating role of social integration in our investigation of the impact of income on Catholics' church attendance. Social integration - "the existence or quantity of social ties" (House, Umberson and Landis 1988:302) - leads to greater church attendance (Estus and Overington 1970; Welch and Baltzell 1984), specifically within the 
Catholic community (Carlos 1970). Social integration provides individuals and families both more to lose from not attending church and more to gain from attending church (Lenski 1963; Welch and Baltzell 1984). In other words, social integration makes it more likely that church attendance is normative. The adjustment of migrants to the levels of religious participation in their new environments demonstrates both variation in and the influence of normative expectations of church attendance (Stump 1984). Although church attendance is normative in most Christian communities, it is expected that "those with high status will conform most closely to group norms" such as church attendance (Lee 1992:11). Norms of church attendance are likely to be weaker for low-income Catholics than for middle- and high-income Catholics as a result of the strong and positive effect of income on social integration (House, Umberson and Landis 1988), particularly in the U.S. Catholic community (Liu 1960). In general, then, we might expect that low-income Catholics have the least to lose by ignoring norms governing regular church participation (Lee 1992).

For more socially integrated, low-income Catholics, however, the normative expectations of church attendance can be enhanced through the same social integration mechanisms that are typically associated with greater income. Relatively socially integrated, low-income Catholics - even though they are fewer proportionally - can therefore be expected to attend church at rates similar to higher-income Catholics. When the normative expectations of church attendance are promoted through mechanisms of social integration other than those associated with income, income should have little effect on church attendance. Previous research concludes that the effects of social class on religious participation are largely, though not solely, a reflection of the effects of social class on social integration (e.g., Goode 1966; Mueller and Johnson 1975). Instead of explaining away the effect of income on church attendance as previous research suggests (Mueller and Johnson 1975), we argue that social integration mechanisms operate as moderating factors in the relationship between income and church attendance. Specifically, income has a positive effect on church attendance for Catholics who are at least somewhat socially isolated.

\section{Data and Methods}

We examine variations in church attendance using data from the 1972-2006 cumulative General Social Survey. The GSS is a nationally representative, cross-sectional survey of non-institutionalized American adults, which is conducted annually or biennially (Davis, Smith and Marsden 2007). There are 26 GSS surveys from 1972 through 2006. Other than the analyses presented in Figure 1, all analyses are limited to respondents who indicate affiliation with the Catholic religion. The central variables 
in our analyses are real family income (in 1986 dollars) and frequency of religious service attendance. We use the log of real family income as our primary independent variable. Employing the log of income limits heteroscedasticity and assumes a decreasing influence of income by compressing larger values more than smaller values (Krueger et al. 2003), thereby highlighting variations in church attendance between low-income Catholics and middle/high-income Catholics. Although Catholics' social class is rising, the number of low-income Catholics is not trivial. For example, 10 percent of Catholics in the 1972-2006 GSS report family incomes below $\$ 8,600$ and 20 percent report family incomes below $\$ 13,600$ (in 1986 dollars). Among non-Catholics, 14 percent report family incomes below $\$ 8,600$ and almost 26 percent report family incomes below $\$ 13,600$. The dependent variable, frequency of church attendance, is coded never (0), less than once a year (1), once a year (2), several times a year (3), once a month (4), two to three times a month (5), nearly every week (6), every week (7) and more than once a week (8).

We conduct separate analyses for non-Latino, white Catholics and Latino Catholics. Non-Latino, white Catholics (hereafter referred to as white Catholics) are defined as those respondents who say they are white and have family origins from nations other than Mexico, Puerto Rico or "other Spanish" nations. Respondents with family origins from Mexico, Puerto Rico or "other Spanish" nations are coded as Latino, regardless of race. Based on this coding, 80 percent of the 1972-2006 Catholic GSS sample is white and 20 percent is Latino/non-white. In comparison, 21 percent of non-Catholics in the GSS are non-white or Latino. The majority of Latino/ non-white Catholics are Latino - 70 percent have family backgrounds from Mexico, Puerto Rico or "other Spanish" nations. Conversely, only about nine percent of non-white, non-Catholics in the GSS are Latino. Because the GSS was administered solely in English from 1972 through 2004, it is likely that Latino Americans are underrepresented in the sample. Consequently, even the number of Latino Catholics is relatively small.

Aside from the age, period and cohort analysis, all results are based on Ordinary Least Squares regressions of frequency of church attendance. We use linear, cross-classified random-effects models to analyze age, period and cohort changes in the effect of income on church attendance. These models adjust for the hierarchical structure of cross-sectional age, period and cohort data and avoid the "identification problem" associated with the linear dependency between age, period and cohort (Yang and Land 2006). Cross-classified, random-effects models provide two ways for us to test for changes in the effect of income across cohorts and/or time periods: by allowing the effect of income to vary across cohort and periods (random effects) and by including cross-level interactions between income and dummy variables for cohorts and/or periods (fixed effects). All OLS models 
Figure 1: Frequency of Church Attendance by Income

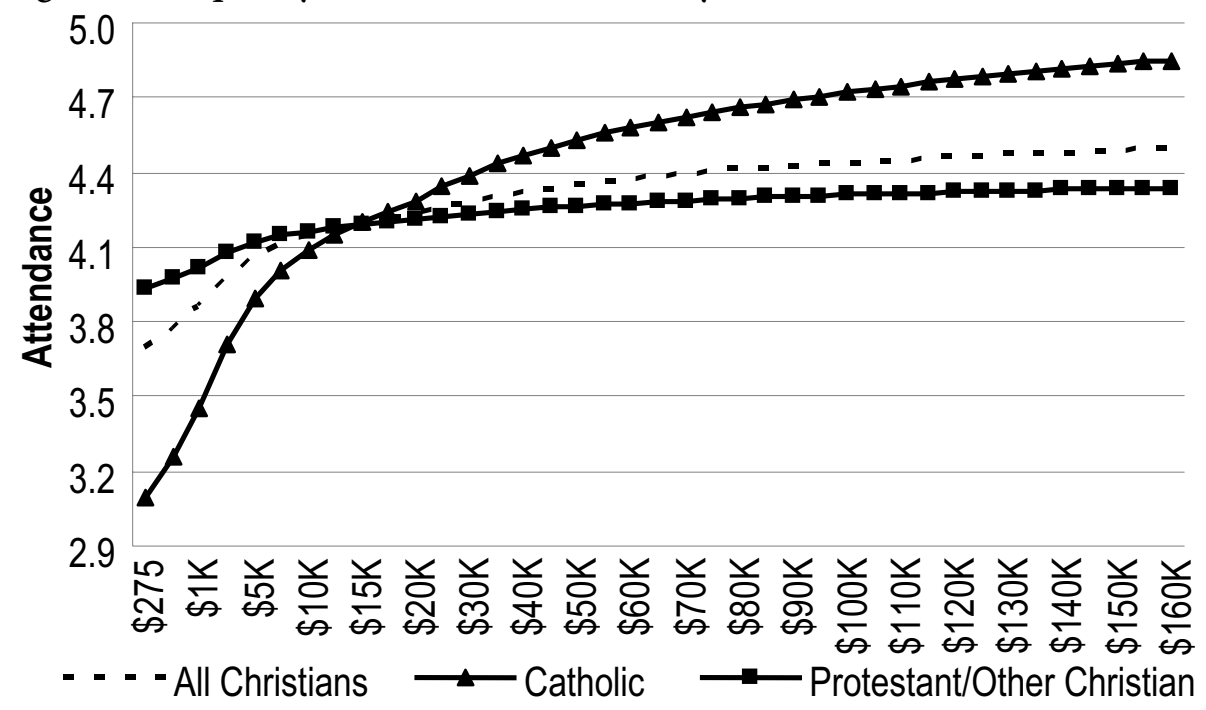

Note: Figure shows results from two OLS regressions of frequency of religious service attendance. "All Christians" line based on regression with one independent variable: log of income $(b=.13)$. "Catholic" and "Protestant/Other Christian" lines based on regression with the following independent variables: log of income $(b=.06)$, Catholic $(b=-2.04)$ and income ${ }^{\star}$ Catholic $(b=.21)$. Cases missing data on sex, age, region, urbanity, education, marital status, children in the home and race are excluded. $\mathrm{N}=$ 37,343. $\mathrm{p}<.05$ for all coefficients (two-tailed test).

are weighted to adjust for the sub-sampling of non-respondents in 2004 and 2006 as well as the number of adults per household and sampling variations in the 1972 through 2002 surveys. We use HLM6 to compute the crossclassified models. Weighting options are not available for cross-classified models. Aside from the preliminary models shown in Figure 1, all models control for children in the home, sex, age, age-square (only in white Catholic models), marital status, urbanity, region of the country and education. ${ }^{2}$

\section{The Impact of Income on Catholics' Church Attendance}

We begin by asking if income affects Christians' church attendance, if the effect of income differs for Catholics and other Christians, and if there are differences between white Catholics and Latino/non-white Catholics. The dashed line in Figure 1 graphs the results from a regression of frequency of church attendance for all Christians, with the log of income as the sole independent variable. As previous research suggests, income appears to have a relatively small, positive effect on church attendance for all 
Christians together. The lowest-income Christians attend slightly less often than other Christians. The other two lines in Figure 1 depict results from a regression of frequency of church attendance for all Christians, with log of income, Catholic affiliation, and an interaction between income and Catholic affiliation as explanatory variables. The graph illustrates that there is little effect of income on the frequency of church attendance among nonCatholic Christians. Among Catholics, however, there is a strong, positive effect of income on the frequency of church attendance. On average, the lowest-income Catholics report attending church only several times a year while the highest-income Catholics report attending church two to three times a month. We also ran a regression of church attendance among Catholics, with log of income, white, and an interaction between income and white as independent variables ( $N=10,724$, results not shown). In this regression, the interaction between white and income has a larger standardized coefficient than either the income or white variables ( $p$-value for all three variables is less than .05). The results from this regression show that the effect of income on Catholics' church attendance is considerably greater for white Catholics than for non-white Catholics.

Our preliminary analyses show that income has little effect on Christians' frequency of church attendance when there are no distinctions made between Catholics and other Christians. Income, however, has a large, positive effect on Catholics' attendance, especially white Catholics. Given these apparently substantial racial/ethnic differences, the next step is to separately analyze white Catholics' church attendance and Latino/non-white Catholics' church attendance, as we add control variables to the models.

Results from separate OLS regressions of frequency of church attendance for white Catholics and Latino/non-white Catholics are presented in Table 1. The bivariate models (1-A and 1-F) show that income has a significant, positive effect on church attendance for both white Catholics and Latino/non-white Catholics, but the magnitude of the effect of income is almost three times larger for white Catholics than for Latino/ non-white Catholics. With the addition of control variables to the model, the effect of income is no longer statistically significant for Latino/nonwhite Catholics (Model 1-G). ${ }^{3}$ Income appears to act as a proxy for certain demographic factors, particularly marriage and education, among Latino/ non-white Catholics. Conversely, income remains a strong predictor of white Catholics' church attendance with control variables in the model (Model 1-B). Only age and sex have larger standardized coefficients than income in Model 1-B (standardized coefficients not shown).

Previous research suggests that the effect of income on church participation reflects low-income Christians' lack of social integration (Goode 1966; Mueller and Johnson 1975). That research concluded that there should be little effect of income on church attendance when 
Table 1: OLS Regressions of Catholics' Church Attendance

\begin{tabular}{|c|c|c|c|c|c|c|c|}
\hline & \multicolumn{5}{|c|}{ White } & \multicolumn{2}{|c|}{ Latino/Non-White } \\
\hline & 1-A & 1-B & $1-C$ & 1-D & 1-E & $1-\mathrm{F}$ & 1-G \\
\hline Income (log) & $\begin{array}{c}.37^{* \star \star} \\
(7.86)\end{array}$ & $\begin{array}{c}.34^{* \star *} \\
(6.72)\end{array}$ & $\begin{array}{c}.30^{\star * *} \\
(5.91)\end{array}$ & $\begin{array}{c}.37^{* \star *} \\
(5.96)\end{array}$ & $\begin{array}{c}.39^{* * *} \\
(6.40)\end{array}$ & $\begin{array}{c}.13^{\star \star} \\
(2.54)\end{array}$ & $\begin{array}{c}.02 \\
(.29)\end{array}$ \\
\hline Income*Org. Memberships & - & - & 一 & $\begin{array}{c}-.06^{* *} \\
(-1.97)\end{array}$ & - & - & - \\
\hline Income*Full-Time Work & - & - & - & - & $\begin{array}{c}-.26^{* * *} \\
(-2.63)\end{array}$ & - & - \\
\hline Children in Home & - & $\begin{array}{c}.44^{* * *} \\
(5.01)\end{array}$ & $\begin{array}{c}.38^{* * *} \\
(4.31)\end{array}$ & $\begin{array}{c}.39^{\star * *} \\
(4.43)\end{array}$ & $\begin{array}{c}.38^{\star \star \star \star} \\
(4.33)\end{array}$ & - & $\begin{array}{c}.25^{* *} \\
(2.33)\end{array}$ \\
\hline Female & - & $\begin{array}{c}.70^{* * \star} \\
(9.05)\end{array}$ & $\begin{array}{c}.74^{* * *} \\
(9.20)\end{array}$ & $\begin{array}{c}.74^{* * *} \\
(9.19)\end{array}$ & $\begin{array}{c}.72^{\star * *} \\
(8.94)\end{array}$ & - & $\begin{array}{c}.62^{\star * *} \\
(6.26)\end{array}$ \\
\hline Age & - & $\begin{array}{c}.04^{\star \star *} \\
(13.54)\end{array}$ & $\begin{array}{c}.03^{* \star *} \\
(12.55)\end{array}$ & $\begin{array}{c}.04^{* * *} \\
(12.68)\end{array}$ & $\begin{array}{c}.04^{\star * *} \\
(12.79)\end{array}$ & - & $\begin{array}{l}.03^{* * *} \\
(6.38)\end{array}$ \\
\hline Age-Square $\left({ }^{*} 100\right)$ & - & $\begin{array}{c}.03^{* *} \\
(2.03)\end{array}$ & $\begin{array}{r}.03^{*} \\
(1.85)\end{array}$ & $\begin{array}{r}.03^{*} \\
(1.84)\end{array}$ & $\begin{array}{r}.03^{*} \\
(1.93)\end{array}$ & - & - \\
\hline Married & - & $\begin{array}{c}.05 \\
(.50)\end{array}$ & $\begin{array}{c}.05 \\
(.55)\end{array}$ & $\begin{array}{c}.05 \\
(.54)\end{array}$ & $\begin{array}{c}.06 \\
(.61)\end{array}$ & - & $\begin{array}{c}.56^{\star \star *} \\
(5.22)\end{array}$ \\
\hline Urban & - & $\begin{array}{c}-.02 \\
(-.17)\end{array}$ & $\begin{array}{l}.02 \\
(.23)\end{array}$ & $\begin{array}{c}.02 \\
(.24)\end{array}$ & $\begin{array}{c}.03 \\
(.30)\end{array}$ & - & $\begin{array}{c}-.05 \\
(-.46)\end{array}$ \\
\hline East & - & $\begin{array}{c}.53^{* * *} \\
(5.42)\end{array}$ & $\begin{array}{c}.54^{* * *} \\
(5.57)\end{array}$ & $\begin{array}{c}.54^{\star * \star} \\
(5.51)\end{array}$ & $\begin{array}{c}.55^{\star \star *} \\
(5.60)\end{array}$ & - & $\begin{array}{c}-.11 \\
(-1.09)\end{array}$ \\
\hline Education & - & $\begin{array}{l}.10^{* * *} \\
(6.53)\end{array}$ & $\begin{array}{c}.07^{* * *} \\
(4.31)\end{array}$ & $\begin{array}{l}.07^{* * *} \\
(4.37)\end{array}$ & $\begin{array}{c}.07^{\star \star *} \\
(4.45)\end{array}$ & - & $\begin{array}{c}.05^{\star * \star} \\
(3.18)\end{array}$ \\
\hline Organization Memberships & - & - & $\begin{array}{c}.22^{\star * *} \\
(8.97)\end{array}$ & $\begin{array}{c}.81^{* \star *} \\
(2.67)\end{array}$ & $\begin{array}{c}.22^{* * *} \\
(9.05)\end{array}$ & - & - \\
\hline Full-Time Work & - & - & $\begin{array}{c}-.17^{* *} \\
(-2.01)\end{array}$ & $\begin{array}{c}-.17^{*} \\
(-2.00)\end{array}$ & $\begin{array}{l}2.49^{* *} \\
(2.45)\end{array}$ & - & - \\
\hline Constar & .86 & -1.90 & -1.40 & -2.14 & -2.27 & 2.88 & 2.13 \\
\hline Adjusted R-Square & .02 & .09 & .11 & .11 & .11 & .00 & .06 \\
\hline
\end{tabular}

Note: T-ratios in parentheses. Latino/non-white sample not limited to surveys with organization membership questions. White $\mathrm{N}=3,761$. Non-White $\mathrm{N}=1,956$ ${ }^{*} \mathrm{p} \leqslant .1 \quad{ }^{* *} \mathrm{p} \leqslant .05 \quad{ }^{* * *} \mathrm{p} \leqslant .01$ (two-tailed test)

controlling for social integration. Because the effect of income is negligible for Latino/non-white Catholics with control variables in the model, we only test this proposition here among white Catholics. Being integrated into the workforce through employment and into social life through participation in organizations are both standard mechanisms expected to enhance social integration (Guest and Stamm 1993; Pollock III 1982). Secular organizational participation in particular is believed to attenuate the relationship between income and church attendance (Goode 1966; Mueller and Johnson 1975). The organizational membership variable is the number of different types of non-church organizations in which a 
respondent reports membership. ${ }^{4}$ The full-time work variable is a dummy variable indicating those respondents who worked fulltime during the week before the survey was administered. ${ }^{5}$

Model 1-C demonstrates that the addition of measures of non-church organizational membership and full-time work to the model lead to only a slight reduction in the effect of income on white Catholics' church attendance. The standardized coefficient for income is larger than the standardized coefficient for all other variables except sex, age and number of nonchurch organizations in Model 1-C (standardized coefficients are not shown). Given that income continues to have a strong effect on white Catholics' church attendance with these two social integration factors included in the model, the question remains: do social integration factors moderate the relationship between income and white Catholics' church attendance?

\section{Moderating Factors for White Catholics}

We argue that the impact of income on Catholics' church attendance is largely restricted to relatively socially isolated Catholics. Thus, rather than "controlling away" the effect of income, organizational membership and full-time work should act as moderating factors on the relationship between income and white Catholics' church attendance. Models 1-D and $1-E$ in Table 1 test this proposition with an interaction between income and non-church organizational membership and an interaction between income and full-time work. As Model 1-D shows, there is a strong and significant interaction between income and non-church organizational memberships. There is little or no effect of income on church attendance for white Catholics with multiple types of organization memberships. For example, among white Catholics with six non-church organization memberships, the difference in attendance between those at the lowest end of the income continuum and those at the upper end is only .21 on the nine-category church attendance measure. Conversely, income has a strong, positive effect on church attendance for white Catholics with few or no organization memberships. For white Catholics with no organization memberships, those at the lowest end of the income continuum attend once to several times a year, while those at the upper end attend about two to three times a month (a difference of 2.38 on the church attendance measure). Similarly, the results in Model 1-E show that there is a meaningful interaction between income and full-time work. Income has little impact on frequency of church attendance for white Catholics with full-time jobs while it has a large, positive effect on church attendance for white Catholics without full-time jobs. Among white Catholics who do not work full time, the poorest attend church fewer than several times a year while the richest attend between two to three times a month and nearly every week. 
We also examine the role of two personal finance-related factors other than income that are expected to be related to social integration: financial mobility and feelings of relative deprivation. Recent financial mobility can be expected to inhibit social integration (Blau 1956; Kessin 1971; Stern and Noe 1973). Feelings of relative status deprivation have also been shown to be associated with low levels of social integration (Francis 1992). Our proposition that income has the greatest effect on church attendance among those who are more socially isolated implies that income has particularly large effects on church attendance among those who recently experienced financial mobility and those who feel relatively status deprived. Financial mobility is measured with dummy variables for respondents who report that during the past few years their financial situation has gotten better and those that report that during the last few years their financial situation has gotten worse. Respondents with financial situations that did not change are the reference category. ${ }^{6}$ Feelings of relative deprivation are measured with a variable gauging whether respondents feel that compared to other American families their family's income is far below average, below average, average, above average or far above average. ${ }^{7}$

Figure 2 graph results from OLS regressions of white Catholics' church attendance with interactions between income and financial mobility measures and an interaction between income and feelings of relative deprivation. To save space the sequential models are not shown, but it is important to note that before adding interaction terms to the model, income remained a strong predictor of white Catholics' church attendance with both the financial mobility and relative deprivation measures in the equivalent model. In other words, neither of these finance-related social integration factors appears to act as a proxy for income. Yet, as Figure 2 demonstrates, both financial mobility and feelings of relative deprivation moderate the effect of income on white Catholics' church attendance. The regression depicted in the first frame of Figure 2 shows that income has a strong, positive effect on white Catholics' church attendance for those who report that their financial situation has gotten better or gotten worse but not for those who report that their financial situation has not changed. Similarly, income has a considerable, positive effect on church attendance for white Catholics who perceive their incomes as below average while income has little effect on church attendance for those who view their incomes as above average (second frame of Figure 2). In summary, the regressions depicted in Figure 2 demonstrate that the positive effect of income on white Catholics' church attendance is predominantly restricted to white Catholics whose financial situation is unstable and those who feel at least somewhat financially deprived.

The presence of children in the home is the final moderating factor we examine in this section. The well-established correlation between 
the presence of children in the home and social integration goes back at least to Durkheim's (1951) research on suicide. Contemporary research confirms that Americans with children in the home tend to be highly socially integrated (Guest and Stamm 1993; Ihinger-Tallman and Pasley 1986). Having children in the home is also associated with greater frequencies of church attendance (Hoge and Roozen 1979; Nash and Berger 1962). The positive correlation between children and social integration suggests that the effect of income on white Catholics' church attendance should be especially robust for those without children, and conversely attenuated among those with children.

Figure 3 graphs results from a regression of white Catholics' church attendance with an interaction between income and children in the home. ${ }^{8}$ Contrary to our expectation, the positive effect of income on white Catholics' church attendance is particularly strong for those with children in the home compared to those without children in the home. Moreover, the often-noted positive impact of children in the home on church attendance applies only to middle- and high-income white Catholics. At the low end of the income range, white Catholics with children in the home are no more likely to attend church than are those without children in the home.

The results of the regression of church attendance with an interaction between children in the home and income were initially quite puzzling to us. After re-reviewing the previous work on social class and religious participation, however, we found earlier suggestions that the impact of children on church attendance varies by social class. Mueller and Johnson (1975:798), for example, observe that "higher SES individuals, compared to lower SES persons, more commonly either subscribe to beliefs about the value of religious training for young children or conform to norms which define the correctness of such activity." If holding norms connecting children and church attendance increases with greater levels of income, as Mueller and Johnson suggest, then the effect of income on church attendance should be stronger among those with children in the home, which is what we find. Unlike the other mechanisms of social integration, then, the integrating influence of children, particularly in relation to church participation, appears to be confined to middle- and upperincome, white Catholics.

With the exception of the presence of children in the home, the analyses of moderating factors in the relationship between income and white Catholics' church attendance support our expectation that the effect of income on Catholics' church attendance is greatest among those Catholics who are most socially isolated. Next, we turn to changes in the relationship between income and white Catholics' church attendance by birth cohort, period and age. 
Figure 2: Frequency of White Catholics' Church Attendance by Income with Changes in Financial Situation and View of Family Income Interactions Income*Financial Situation

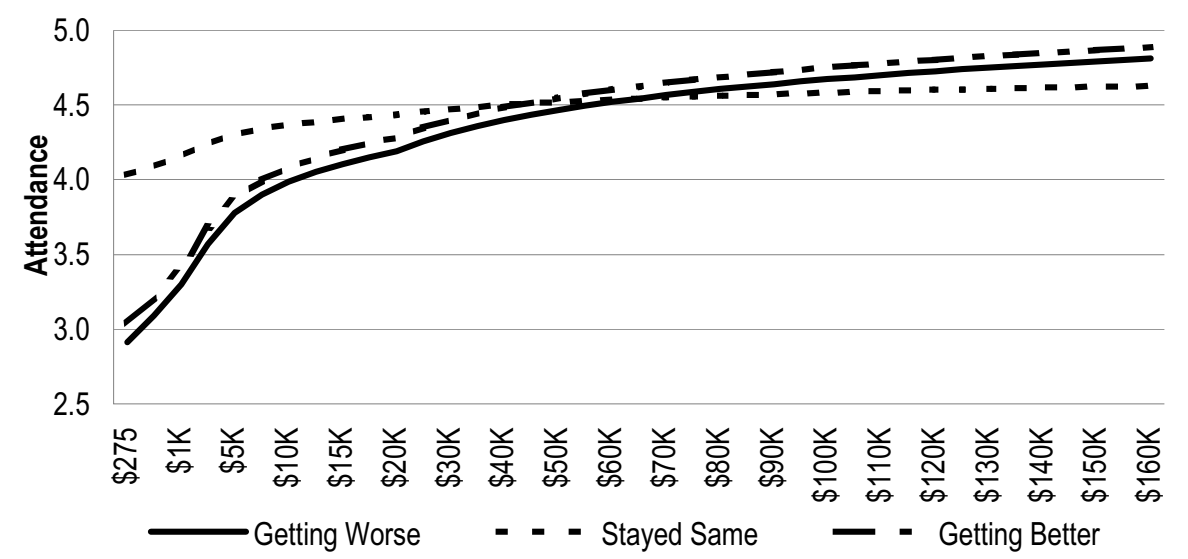

Income*View of Income

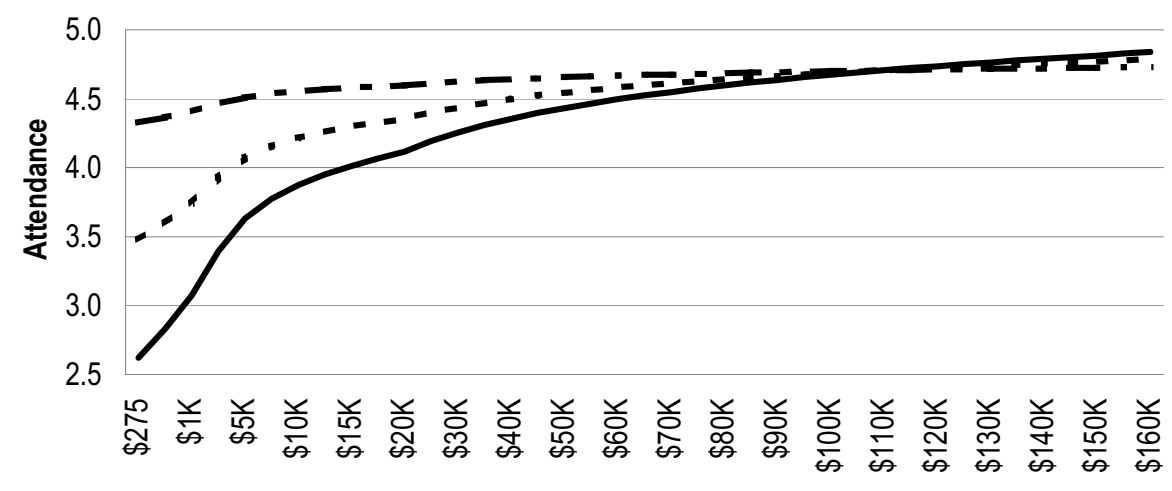
Far Below Average - _ - Average _ - Far Above Average

Note: Based on two OLS regressions of frequency of religious service attendance. First frame primary independent variables: $\log$ of income $(b=.09)$, finances getting better $(b=-2.10)$, finances getting worse $(b=-2.27)$, income ${ }^{\star}$ finances getting better $(b=$ $.20)$ and income ${ }^{\star}$ finances getting worse $(b=.21)$. Second frame primary independent variables: log of income $(b=.42)$, view of income $(b=.83)$ and income view of income $(b=-.07)$. Control variables (sex, age, age-square, education, marital status, urban, east, children in the home, finances getting better, finances getting worse and view of family income) are set at their means (when not graphed). $\mathrm{p}<.05$ for all interactions (two-tailed test). $\mathrm{N}=8,134$. 


\section{Age, Period and Cohort Differences for White Catholics}

In relation to period and cohort changes, the rising social status of American Catholics suggests that income differences in church attendance have been increasing. As low-income, white Catholics become a smaller minority in their churches, their frequency of church attendance may correspondingly decrease. This change can take the form of a difference between periods (survey years) or across birth cohorts. Yet, declines in Catholics' church attendance are generally the result of lower levels of attendance among younger birth cohorts rather than declines in attendance among all Catholics over time (Firebaugh and Harley 1991). Cohort changes in white Catholics' social integration further suggest that the effect of income on church attendance varies by cohort. Social capital researchers, for example, emphasize a generational decline in social participation (Putnam 1995). Specific to American Catholics, those who matured after Vatican II focus less on Mass attendance and place more importance on an individual's relationship with God than do previous cohorts of Catholics (D'Antonio et al. 1996; Davidson et al. 1997). We follow Davidson and his colleagues (1997) and D'Antonio and his coauthors (1996) by dividing Catholics into three birth cohorts: those who matured before Vatican II (born before 1941), those who were children or young adults at the time of Vatican II (born 1941-1960) and those who matured after Vatican II (born after 1960). Each of the 26 GSS surveys from 1972 through 2006 is treated as a separate period.

In addition to possible period and cohort changes, the relationship between age and social integration suggests that the effect of income on white Catholics' church attendance may vary by age. Age typically has a curvilinear effect on social integration. In general, social participation rises from the early 20s through middle age and then declines thereafter (Cutler and Hendricks 2000; Knoke and Thomson 1977; Rotolo 2000; Scammon 1967). Assuming that the youngest and oldest Catholics are the most socially isolated, income should have the largest effect on church attendance among these age groups.

Results from linear, cross-classified random effects age-period-cohort models of white Catholics' church attendance are reported in Table 2. In multilevel analysis vernacular, cross-classified models treat period and cohort as overlapping level-2 units of analysis and individuals as level-1 units of analysis (Yang and Land 2006). Each respondent is nested in both a birth cohort and a specific survey year. These models not only avoid the "identification problem" with age, period and cohort analyses, but they also allow us to test for variation in the effect of income across periods and cohorts with random slopes for income. If the slope of income varies meaningfully across periods or cohorts, then the impact of income on church attendance changes either by period or by cohort. 
Figure 3: Frequency of White Catholics' Church Attendance by Income, with Income ${ }^{\star}$ Children in the Home Interaction

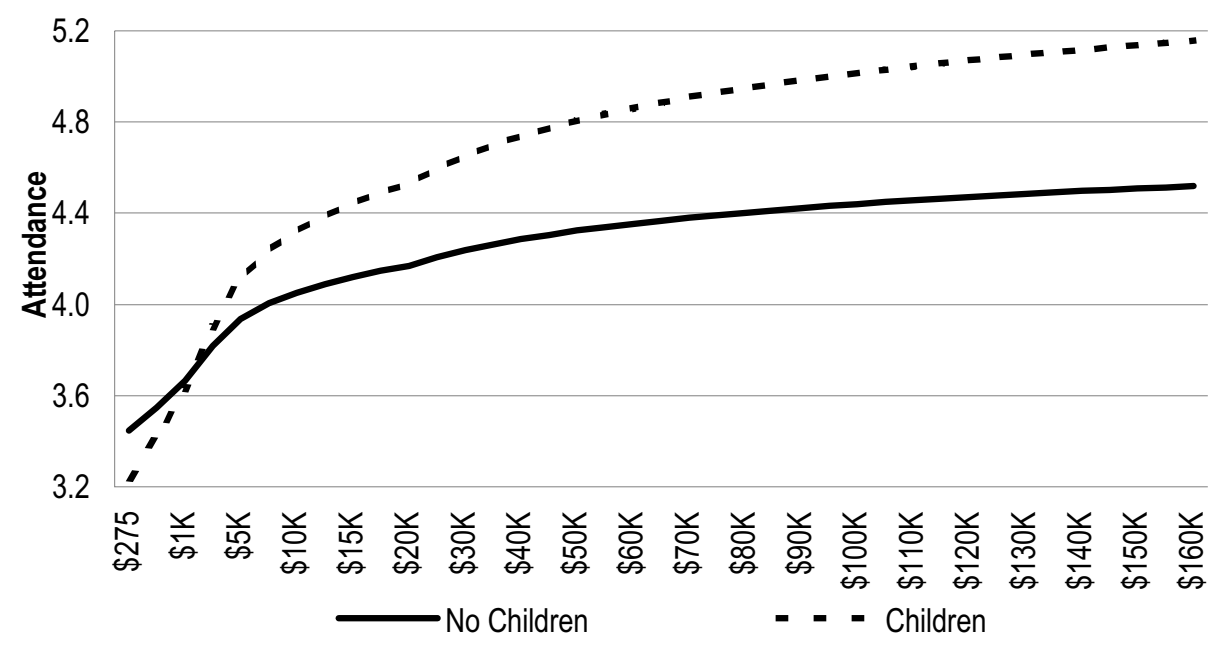

Note: Based on OLS regression of frequency of religious service attendance.

Primary independent variables: $\log$ of income $(b=.17)$, children $(b=-.96)$ and income ${ }^{\star}$ children $(b=.13)$. Control variables (sex, age, age-square, education, marital status, urban, east, finances getting better, finances getting worse and view of family income) are set at their means. $\mathrm{p}<.05$ for interaction (two-tailed test). $\mathrm{N}=8,134$.

Model 2-A is the base model, containing only individual-level independent variables without interactions or random slopes for income. Similar to the OLS models, income has a strong, positive effect on white Catholics' church attendance in this first model. Although we are not focused on changes in church attendance unrelated to income, the variance components for cohort and period are both significant, indicating meaningful variation in white Catholics' church attendance across period and cohorts.

Model 2-B tests for variations in the effect of income by age with an interaction between income and age and an interaction between income and age-square. The large, negative coefficient for the interaction between income and age denotes that the effect of income initially decreases as age increases. The positive interaction between income and age-square means that at some point in the age range the effect of income begins to increase as age increases. Specifically, income has a strong, positive effect on church attendance for young adult, white Catholics while the effect of income is relatively small for white Catholics 40-60 years of age. Among older white Catholics, particularly older than 70 , those with low levels of income are far less likely than higher-income Catholics to attend church. 
Model 2-C tests for changes in the effect of income across periods and cohorts by allowing the slope of income to vary randomly by period and cohort. The variance component for the slope of income across periods is not significant, demonstrating that the effect of income does not vary meaningfully by period. Conversely, the variance component for the slope of income across cohorts is significant, suggesting meaningful variation in the effect of income by cohort. Model 2-D looks at how the effect of income varies across cohorts with interactions between income and birth cohorts. ${ }^{9}$ The significant, positive interaction between income and the post-1960 cohort indicates an increase in the effect of income between the pre-1941 cohort and the post-1960 cohort. The difference in church attendance between low-income, white Catholics and middle/highincome, white Catholics is considerably greater for the post-1960 cohort than for the pre-1941 cohort. In relation to previous research pointing to differences in church attendance between pre-Vatican II and post-Vatican II Catholics (e.g., D'Antonio et al. 1996; Davidson et al. 1997), the results show that these cohort differences are greatest among low-income, white Catholics. More importantly, the GSS data demonstrate an increase in the effect of income on white Catholics' church attendance between cohorts, but no increase in the effect of income across periods.

In summary, then, these analyses have shown that the effect of income on white Catholics' church attendance varies by both birth cohort and age. Low-income, white Catholics born after 1960 have particularly low levels of church attendance, regardless of age. In regards to age, the positive effect of income on white Catholics' church attendance is largely restricted to the oldest and youngest (adult) white Catholics. Again, it is the most socially isolated white Catholics - those who matured after Vatican II and those at the extremes of the age range - whose church attendance is most affected by family income.

\section{White Catholics' Personal Religiosity and Religious Beliefs}

Although low-income, white Catholics display particularly low levels of church attendance this does not mean they are not religious. Influenced by Niebuhr's writings, previous research points to the otherworldly and experience-based emphasis of lower-class religion and the participationoriented, more "church-like" focus of middle- and upper-class religion (Demerath 1965; Fukuyama 1961; Lenski 1963; Stark 1972). The above findings support the notion that the religion of middle- and high-income, white Catholics is particularly church based. Does that mean that lowincome, white Catholics are disproportionately likely to stress the importance of personal religiosity and religious beliefs, as Niebuhr and others suggested? 
Table 2: Linear, Cross-Classified Random Effects Models of White Catholics' Church Attendance

\begin{tabular}{|c|c|c|c|c|}
\hline & $2-A$ & 2-B & $2-C$ & $2-D^{a}$ \\
\hline \multicolumn{5}{|l|}{ Income } \\
\hline$(\log )$ & $\begin{array}{l}.21^{* * *} \\
(6.21)\end{array}$ & $\begin{array}{c}.12^{\star * \star} \\
(2.74)\end{array}$ & $\begin{array}{c}.21^{* * *} \\
(5.73)\end{array}$ & $\begin{array}{l}.16^{* * *} \\
(3.08)\end{array}$ \\
\hline${ }^{*}$ Age $\left({ }^{*} 100\right)$ & - & $\begin{array}{c}-.36^{* *} \\
(-2.03)\end{array}$ & - & - \\
\hline${ }^{*}$ Age-Square (*100) & 一 & $\begin{array}{c}.03^{* * *} \\
(2.89)\end{array}$ & 一 & - \\
\hline Children in Home & $\begin{array}{c}.31^{* \star *} \\
(5.07)\end{array}$ & $\begin{array}{c}.32^{\star * *} \\
(5.18)\end{array}$ & $\begin{array}{c}.31^{* * *} \\
(5.07)\end{array}$ & $\begin{array}{l}.30^{* \star *} \\
(5.00)\end{array}$ \\
\hline Female & $\begin{array}{c}.70^{\star \star \star} \\
(13.58)\end{array}$ & $\begin{array}{l}.70^{\star * *} \\
(13.64)\end{array}$ & $\begin{array}{c}.70^{\star \star \star *} \\
(13.54)\end{array}$ & $\begin{array}{c}.70^{\star * \star} \\
(13.49)\end{array}$ \\
\hline Age & $\begin{array}{c}.04^{* \star *} \\
(11.99)\end{array}$ & $\begin{array}{c}.07^{\star * \star} \\
(4.07)\end{array}$ & $\begin{array}{c}.04^{* * *} \\
(11.21)\end{array}$ & $\begin{array}{l}.03^{* * *} \\
(9.00)\end{array}$ \\
\hline Age-Square $(* 100)$ & $\begin{array}{c}.03^{\star * *} \\
(2.80)\end{array}$ & $\begin{array}{c}-.24^{* * *} \\
(-2.60)\end{array}$ & $\begin{array}{c}.03^{* * *} \\
(2.84)\end{array}$ & $\begin{array}{l}.03^{* * *} \\
(2.90)\end{array}$ \\
\hline Married & $\begin{array}{l}.27^{\star * \star} \\
(4.41)\end{array}$ & $\begin{array}{c}.29^{\star * *} \\
(4.76)\end{array}$ & $\begin{array}{c}.27^{\star \star \star} \\
(4.43)\end{array}$ & $\begin{array}{l}.28^{* * *} \\
(4.54)\end{array}$ \\
\hline Urban & $\begin{array}{c}-.18^{* * *} \\
(-2.69)\end{array}$ & $\begin{array}{l}-.17^{\star * \star} \\
(-2.65)\end{array}$ & $\begin{array}{c}-.18^{* \star *} \\
(-2.70)\end{array}$ & $\begin{array}{l}-.18^{\star * \star} \\
(-2.68)\end{array}$ \\
\hline East & $\begin{array}{c}.44^{\star * *} \\
(6.98)\end{array}$ & $\begin{array}{c}.44^{\star * *} \\
(6.93)\end{array}$ & $\begin{array}{c}.44^{\star * *} \\
(6.98)\end{array}$ & $\begin{array}{l}.44^{* * *} \\
(6.96)\end{array}$ \\
\hline Education & $\begin{array}{c}.14^{* * *} \\
(14.11)\end{array}$ & $\begin{array}{c}.15^{\star \star *} \\
(14.32)\end{array}$ & $\begin{array}{c}.14^{* * *} \\
(14.18)\end{array}$ & $\begin{array}{c}.14^{* * *} \\
(14.19)\end{array}$ \\
\hline Born & & & & \\
\hline $1941-1960^{b}$ & 一 & - & - & $\begin{array}{l}-.58 \\
(-.81)\end{array}$ \\
\hline After $1960^{b}$ & 一 & 一 & 一 & $\begin{array}{l}-1.86^{* *} \\
(-2.26)\end{array}$ \\
\hline Income*Born 1941-1960 & - & 一 & - & $\begin{array}{l}.02 \\
(.24)\end{array}$ \\
\hline Income*Born After 1960 & 一 & 一 & - & $\begin{array}{r}.15^{*} \\
(1.86)\end{array}$ \\
\hline Intercept & 4.41 & 4.42 & 4.41 & 4.66 \\
\hline Individual Variance Component & 5.61 & 5.60 & 5.61 & 5.62 \\
\hline Cohort Variance Component & $.02^{* * *}$ & $.02^{* * *}$ & $.03^{* * *}$ & - \\
\hline Income Slope Variance Component (*100) & 一 & - & $.02^{* * *}$ & - \\
\hline $\begin{array}{l}\text { Period Variance Component } \\
\left.\text { Income Slope Variance Component ( }{ }^{*} 100\right)\end{array}$ & $.18^{* * *}$ & $.18^{* * *}$ & $\begin{array}{l}.17^{\star * *} \\
.15\end{array}$ & $.16^{* * *}$ \\
\hline
\end{tabular}

Note: T-ratios in parentheses. Independent variables grand-mean centered. Level-1 $\mathrm{N}=8,766$.

a There is no random cohort intercept in Model 2-D.

${ }^{b}$ Born before 1941 is the reference category.

${ }^{*} \mathrm{p} \leqslant .1 \quad{ }^{* *} \mathrm{p} \leqslant .05 \quad{ }^{* *} \mathrm{p} \leqslant .01$ (two-tailed test) 
Alert to this possibility, we briefly examine the effects of income on white Catholics' religious beliefs and personal religiosity using the same 1972-2006 GSS data. Table 3 reports coefficients for the log of income from regressions of white Catholics' personal religiosity and religious beliefs. These models also control for sex, age, race, education, marital status, children in the home, urbanity and region of the country. The results in Table 3 support the notion that the lower classes do emphasize personal religiosity. Income has a moderate, negative effect on white Catholics' likelihood of considering themselves religious. Additionally, income has a strong, negative effect on finding strength and comfort in religion. ${ }^{10}$ When it comes to religious beliefs, income has little impact on belief in the afterlife but a large, negative effect on viewing the Bible as the literal word of God. ${ }^{11}$ These results suggest that while low-income, white Catholics are unlikely to regularly attend church, they are far from irreligious. Low-income, white Catholics are more likely than middle- and high-income, white Catholics to say they are religious, to find strength and comfort in religion, and to view the Bible as the literal word of God. The results in Table 3 also provide some support for the view that "sect-like" religion among the lower classes and "church-like" religion among the middle and upper classes can coexist within the same religious tradition (Demerath 1965).

\section{Moderating Factors for Latino Catholics}

Thus far, the results have largely supported our proposition that that the positive effect of income on Catholics' church attendance is predominantly limited to socially isolated Catholics. In this final analytic section, we ask how social isolation affects Latino Catholics' church attendance. Although income has little overall effect on Latino Catholics' attendance (see Table 1 and Note 3), it is possible that income differentially affects more socially isolated compared with less socially isolated Latino Catholics. ${ }^{12}$ Isolation from the Latino community in particular may create a context where the effect of income on church attendance is exacerbated.

We begin by looking at the moderating roles of non-church organization memberships and full-time work. ${ }^{13}$ As with white Catholics, there is a meaningful interaction between income and non-church organization memberships (first frame of Figure 4). The pattern of the interaction, however, does not mimic that seen for white Catholics. While income has a strong, positive effect on church attendance for white Catholics with no organization memberships, income has little effect on church attendance for Latino Catholics with no organization memberships. Among Latino Catholics with non-church organization memberships, income has a negative effect on church attendance. Similarly, the results in the second frame of Figure 4 show a significant interaction between income and full-time work. The 
Table 3: Effect of Log of Income from Regressions of Personal Religiosity and Religious Beliefs

\begin{tabular}{llc}
\hline Dependent Variable & Log of Income (b) & N \\
\hline Personal Religiosity & & \\
Consider Self Religious Person $^{\mathrm{a}}$ & $-.08(-1.76)^{*}$ & 463 \\
Find Strength and Comfort in Religion $^{\mathrm{a}}$ & $-.33(-2.68)^{\star \star *}$ & 234 \\
& & \\
Religious Beliefs & $.01(.09)$ & 5,375 \\
Afterlife $^{\mathrm{b}}$ & & 3,580 \\
View of Bible $^{\mathrm{c}}$ & $-.33(33.81)^{\star * *}$ & \\
$\quad$ Word of God & reference & \\
$\quad$ Inspired Word & $-.03(.18)$ & \\
$\quad$ Book of Fables &
\end{tabular}

Note: All models control for sex, age, region, urbanity, education, marital status and children in the home.

a OLS regression. T-ratios in parentheses.

${ }^{\mathrm{b}}$ Binary logistic regression. Wald Statistic in parentheses.

${ }^{\mathrm{c}}$ Multinomial logistic regression. Wald Statistic in parentheses.

${ }^{*} \mathrm{p} \leqslant .1 \quad{ }^{* *} \mathrm{p} \leqslant .05 \quad{ }^{* *} \mathrm{p} \leqslant .01$ (two-tailed test)

interaction between income and full-time work also takes on a different pattern for Latino Catholics than for white Catholics. Income has a small, positive effect on church attendance for Latino Catholics without full-time jobs and a strong, negative effect for Latino Catholics with full-time jobs.

The last two moderating factors we explore are designed to specifically gauge Latino social isolation. Previous research shows that minority group members who display robust norms of church participation in ethnically/racially homogenous communities exhibit substantial declines in attendance outside of these locations (Ellison and Sherkat 1995). In relation to income, Hunt and Hunt (2000) find that income only affects blacks' church attendance in the less close-knit black communities outside of the South. Similarly, the effect of income on participation may vary for Latino Catholics who are more and less embedded in the Latino community. While the cumulative GSS data do not allow us to directly measure embeddedness in the Latino community, we employ geographic indicators as proxies for isolation from the Latino community. ${ }^{14}$

Latino Americans disproportionately live in urban areas. For example, Latinos are more than twice as likely as non-Latino whites to live in the central city of a metropolitan area (U.S. Census Bureau 2000a). Similarly, in the 1972-2006 GSS samples, Latino Catholics are about twice as likely as white Catholics to live in an urban area (35 percent and 18 percent, respectively). If the concentration of Latino residents in urban areas 
promotes integration into more vibrant Latino communities, then income can be expected to have differing effects on church attendance for those living outside of urban areas than for those living in urban areas. As the interaction effect depicted in the first frame of Figure 5 shows, this is indeed the case. Income has a strong, negative effect on church attendance for Latino Catholics living in urban areas and a small, positive effect on church attendance for Latino Catholics living outside of urban areas.

The last moderating factor we explore is geographic mobility. Not only does geographic mobility inhibit social integration (Haynie, South and Bose 2006), but by limiting social integration geographic mobility reduces church attendance (Welch and Baltzell 1984). Geographic mobility is particularly problematic for the social integration of Latino Americans due to the spatial concentration of Latinos, especially low-income Latinos, in specific urban areas (Logan, Stults and Farley 2004). Geographic mobility is measured with a dummy variable indicating respondents who live in a different city, town or county than they did when they were 16 years old. ${ }^{15}$ As the second frame of Figure 5 shows, there is a robust interaction between income and geographic mobility. Income has a considerable, negative effect on Latino Catholics' church attendance for those who live in the same city, town or county as they did when they were 16 years old. On the other hand, income has a relatively strong, positive effect on Latino Catholics' church attendance for those who live in a different city, town or county as they did when they were 16 years old.

The results from the Latino-only analyses do not contradict our view that socially isolated, low-income Catholics are unlikely to attend church. Nonetheless, instead of finding a positive effect of income among socially isolated Latino Catholics (other than the positive effect for geographically mobile Latinos), the results generally show a negative effect of income among socially integrated Latino Catholics. Social integration promotes church attendance among both white and Latino Catholics, but increased income does not appear to act as a social integration mechanism that promotes church attendance for Latino Catholics as it does for white Catholics.

An alternative explanation for why income does not have the same impact on church attendance for Latino Catholics that it does for white Catholics is that white Catholics place more emphasis on work, wealth accumulation and achievement. Such an account is consistent with the arguments Lisa Keister (2007:1200) developed to explain the Catholic advantage in upward wealth mobility, where she concludes that "There is evidence that [white] Catholics tend to have unique values related to work and money." As a result of these values, white Catholics may be more likely to attend church than Latino Catholics in order to expand and deepen their social networks that enhance their opportunities for upward social mobility. 
Figure 4: Frequency of Latino Catholics' Church Attendance by Income, with Income ${ }^{\star}$ Organization Memberships and Income ${ }^{\star}$ Full-Time Work Interactions Income*Organization Memberships
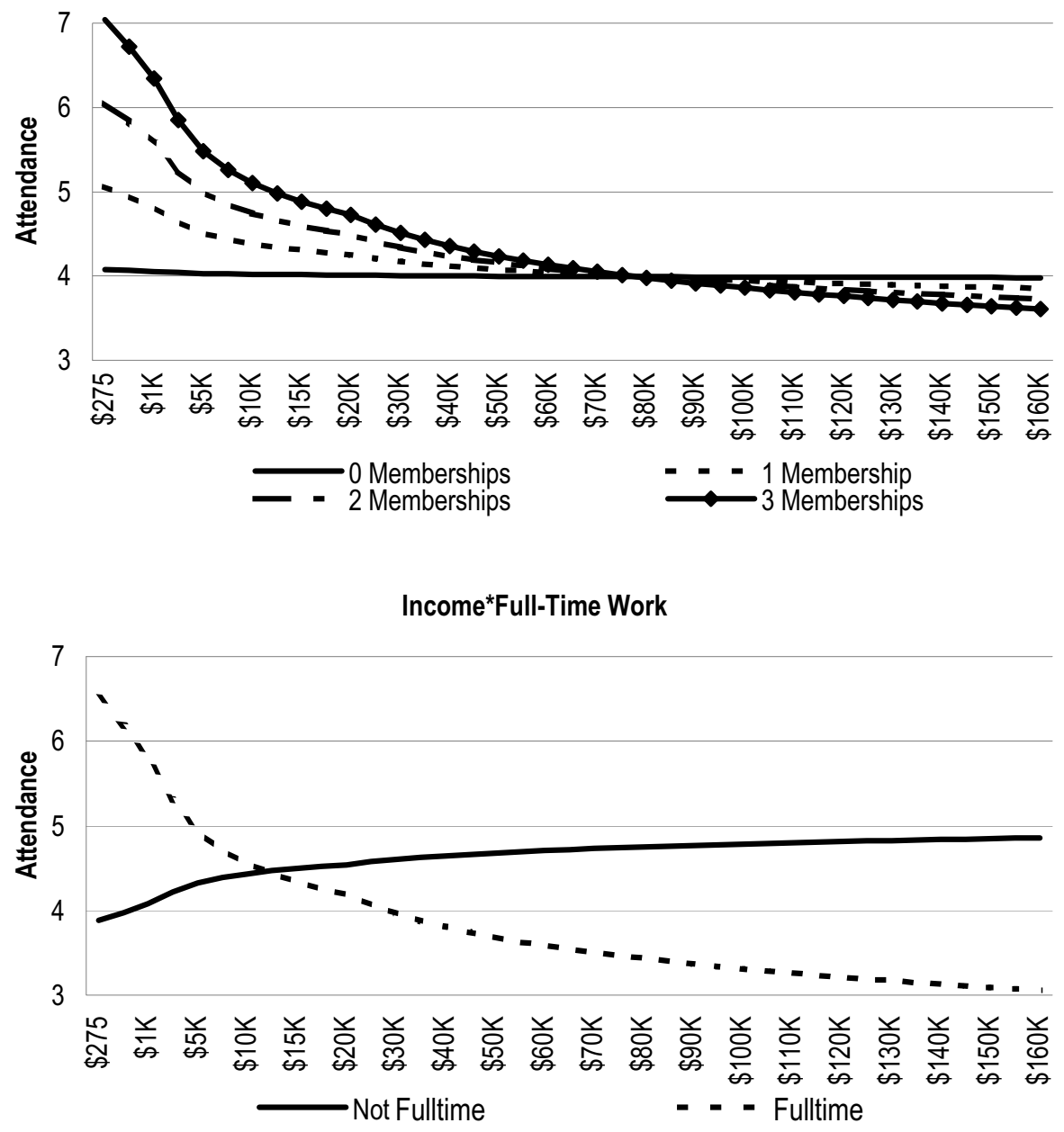

Note: Based on two OLS regressions of frequency of religious service attendance. First frame primary independent variables: log of income $(b=-.01)$, organization memberships $(b=1.98)$ and income ${ }^{\star}$ organization memberships $(b=-.18)$. Second frame primary independent variables: $\log$ of income $(b=.15)$, full-time work $(b=$ $6.52)$ and income ${ }^{\star}$ full-time work $(b=-.70)$. Control variables (sex, age, education, marital status, urban, east, children in the home, foreign born, full-time work and organization memberships) are set at their means (when not graphed). $\mathrm{p}<.05$ for interactions (two-tailed test). $\mathrm{N}=379$. 
In an effort to test this alternative explanation, we scoured the GSS data for items appropriate for evaluating the alternative explanation's hypothesized value differences between white and Latino Catholics. We compare Latino and non-Latino Catholics' emphasis on achievement using several measures. ${ }^{16}$ Bivariate correlations between Latino identification and the achievement-orientation measures are presented in Table $4 .{ }^{17}$ As these correlations show, Latino Catholics are not less achievement oriented than other Catholics. Latino Catholics are not significantly less likely than white Catholics or other non-Latino Catholics to stress the importance of financial security. Similarly, there is no meaningful effect of Latino ancestry on emphasizing the connection between getting ahead and ambition, working hard, knowing the right people and being the right religion. The only significant relationship is a positive correlation between Latino and an emphasis on the importance of work. The correlations in Table 4 demonstrate that Latino Catholics are not less achievement focused than white Catholics, which suggests that white Catholics' emphasis on work and wealth accumulation does not explain the disparity in the effect of income on white and Latino Catholics' church attendance.

\section{Discussion and Conclusions}

The findings from our analyses of Catholics' church attendance challenge the notion, which became popular in the 1970s, that low-income Christians in the United States are as likely as middle- and high-income Christians to attend religious services. Low-income, white Catholics attend church considerably less often than other white Catholics. Income has an especially strong, positive effect on church attendance for white Catholics who are relatively socially isolated (i.e., have few or no nonchurch organization memberships, do not work fulltime, experience recent income mobility, feel relatively income deprived, at the extremes of the age range and matured after Vatican II). We identify one exception to this pattern - income has a strong, positive effect on church attendance for white Catholics with children in the home, who are presumably less socially isolated than those without children in the home. We discuss this finding below in the context of social class variations in the norms connecting children with church attendance. Social isolation also plays a role in the impact of income on Latino Catholics' church attendance. For the most part, income has a negative effect on church attendance for more socially integrated Latino Catholics. The Latino Catholics who attend church most frequently have low incomes and full-time jobs, nonchurch organization memberships, urban residency or are geographically stable. Overall, socially isolated, low-income Catholics are particularly unlikely to attend church. Social integration factors other than those 
Figure 5: Frequency of Latino Catholics' Church Attendance by Income, with Income ${ }^{\star}$ Urban and Income ${ }^{\star}$ Geographically Mobile Interactions

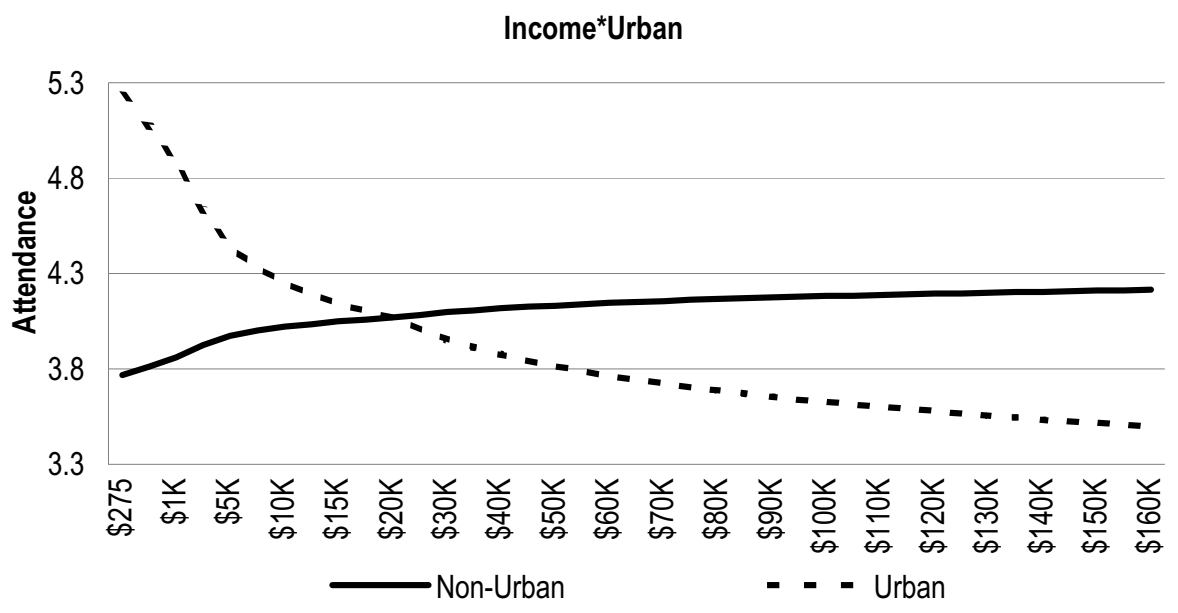

Income*Geographically Mobile

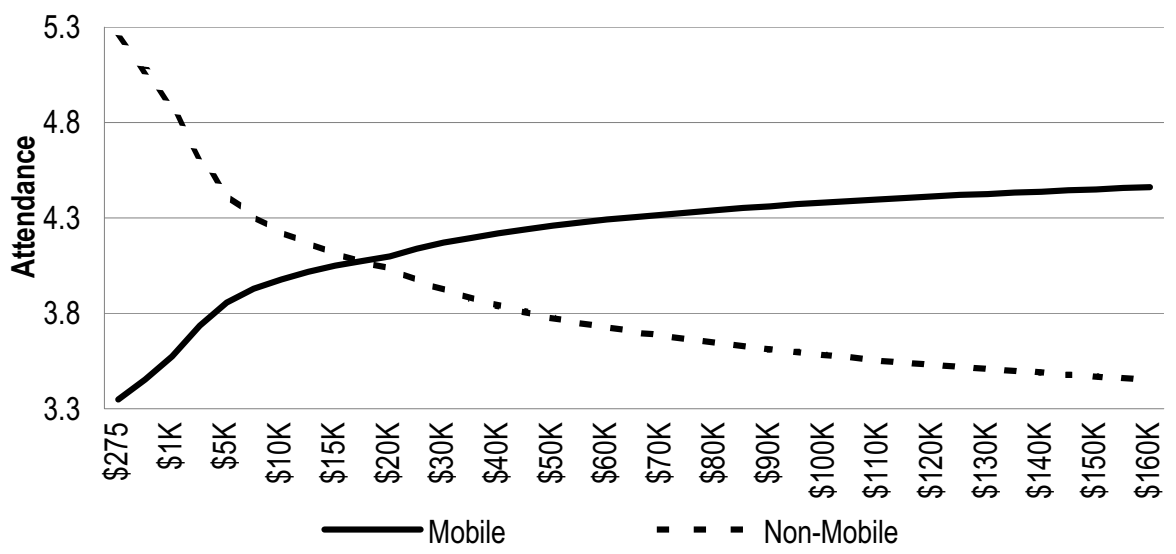

Note: Based on two OLS regressions of frequency of religious service attendance. First frame primary independent variables: $\log$ of income $(b=.07)$, urban $(b=3.39)$ and income $e^{\star}$ urban $(b=-.34)$. Second frame primary independent variables: log of income $(b=-.28)$, geographically mobile $(b=-4.45)$ and income ${ }^{\star}$ geographically mobile $(b$ $=.46$ ). Control variables (sex, age, education, marital status, urban, east, children in the home, foreign born and geographic mobility) are set at their means (when not graphed). $\mathrm{p}<.05$ for interactions (two-tailed test). $\mathrm{N}=1,050$. 
Table 4: Bivariate Correlations between Latino and Achievement Measures

\begin{tabular}{lcc}
\hline & Correlation with Latino & $\mathbf{N}$ \\
\hline Importance of Work and Career & $.12^{* *}$ & 395 \\
Importance of Financial Security & .01 & 348 \\
Need Ambition to Get Ahead & -.06 & 342 \\
Need to Work Hard to Get Ahead & -.07 & 342 \\
Need to Know Right People to Get Ahead & .04 & 618 \\
Need to be Right Religion to Get Ahead & -.03 & 337 \\
\hline
\end{tabular}

Note: Importance of work and career from 1982 survey, importance of financial security from 1993, need to know right people to get ahead from 1987 and 2000, and need ambition to get ahead, need to work hard to get ahead and need to be right religion to get ahead from 1987 .

${ }^{*} \mathrm{p} \leqslant .1 \quad{ }^{* *} \mathrm{p} \leqslant .05 \quad{ }^{* * *} \mathrm{p} \leqslant .01$ (two-tailed test)

associated with income appear to motivate church attendance as well as those associated with income. In the absence of these other integrating factors, however, increased income is expected to be associated with the norm of regular church attendance for white Catholics, but not for Latino Catholics.

Aside from low levels of social integration, other factors may also inhibit low-income Catholics' church attendance. It is plausible that the monetary costs of church participation, for example, outweigh the religious and social/ cultural benefits of church attendance for many socially isolated, low-income Catholics. Max Weber (1946:302) noted long ago that "church affiliation in the U.S.A. brings with it incomparably higher financial burdens, especially for the poor, than anywhere in Germany." More recently, McCloud (2007) outlined the ways in which social class imposes constraints on religious participation. Donating money to a church is the most obvious monetary cost associated with church participation. Other costs include, but are not limited to, purchasing suitable clothing to wear to Mass and affording travel costs to and from church since few Americans live within walking distance of their churches (Chaves 2004). Church participation requires a monetary investment that some low-income Catholics may not be willing or able to afford, given the increased barriers to their choosing a more class compatible congregation, a choice more open to poor Protestants.

In addition to the monetary costs of participation, there is also the question of whether low-income, relatively socially isolated Catholics feel welcome when they attend church. There is a stigma associated with being poor that might lead some low-income Catholics, especially low-income, white Catholics, to shun religious participation. Low-income people sometimes worry that they may not be accepted in church as a result of their clothing and other outward signs of social class (Sakalas 1999); and 
high levels of social status diversity in most Catholic parishes mean that low-income, white Catholics usually attend church with middle- and highincome Catholics (Schwadel 2005). While the Catholic Church is strongly committed to raising the standard of living of the poor, it is possible that it is not doing enough to make individual poor people feel welcome at Mass (Weissbourd 2000). Parish-based efforts addressed at helping the poor can even create a barrier to low-income Catholics' religious participation, consistent with Weissbourd's (2000:223) observation that faith-based social services "can reinforce a hierarchical division between those who provide and those in need."

A striking finding to emerge from our analyses is that the presence of children in the home does not promote church attendance for lowincome, white Catholics. It is generally assumed that adults with children in the home are especially likely to attend church, and this is the case among middle- and high-income Catholics. Low-income, white Catholics with children in the home, however, have particularly low levels of church attendance. It is entirely possible, as Mueller and Johnson (1975) suggest, that middle- and high-income Catholics are more likely than low-income Catholics to subscribe to the norm that a family with children should attend church. Reasoning from the preceding discussion of financial costs associated with church attendance, there may be expectations, or perceived expectations, that children will participate in Sunday school and youth groups, which have associated costs, and possibly even parochial school, which has become prohibitively expensive. Problems associated with feeling accepted in church may also be exacerbated by the presence of children. Children are especially likely to feel alienated in church due to outward signs of poverty in an affluent society. For adolescents in particular, there is a strong sense of marginalization associated with being poor (Phillips and Pittman 2003). The lack of religious participation by low-income, white Catholics with children means that opportunities for both low-income adults and their children to develop vital civic skills and interact with people outside of their often-limited social networks are consequently severely restricted.

Our discussion of the impact of income on Catholics' church attendance has been largely restricted to white Catholics because income has, as we showed, little overall impact on Latino Catholics' frequency of church attendance. We develop an argument that we believe plausibly accounts for these differences. Latino Americans have disproportionately low incomes (Welniak and Posey 2005). The prevalence of ethnic parishes and the large proportion of Latinos with low incomes suggest that low-income Latinos are more likely to be class compatible with their fellow parishioners than low-income, white Catholics are with theirs. In other words, low-income, Latino Catholics are more likely to encounter other lower-class Catholics in 
their parishes. The relatively large proportion of Latino Catholics from lowincome homes may explain why low-income, socially integrated Latino Catholics have especially high levels of church attendance. Low-income Latinos may obtain social and cultural benefits that mitigate the costs of participation through associating with other Latinos, particularly other lowincome Latinos, in their parishes. Low-income whites, on the other hand, are likely to be a small minority in their parishes, are not likely to have much influence over the parish culture and are not likely to receive the ethnicityrelated social and cultural benefits that mitigate the costs of participation. Given the additional benefits of church participation for Latino Catholics, it is not surprising that the positive impact of income on Catholics' church participation is primarily restricted to white Catholics; though, as we have noted, it is somewhat surprising to find that income has a negative effect on church attendance among more socially integrated Latino Catholics.

Not only do low-income, white Catholics have low levels of church attendance, but the effect of income on white Catholics' church attendance increased between birth cohorts. Low-income, white Catholics born after 1960 are particularly unlikely to attend church. Did the Church do something to discourage attendance among low-income Catholics during this time period? Are we seeing lagged effects of Vatican II and Humanae Vitae, the 1968 Papal encyclical on artificial birth control? Are the sexual abuse scandals involving priests that gained national media attention beginning in the 1990s now affecting low-income, white Catholics' church attendance? Perhaps, as previous research suggests about some younger Catholics (Hoge et al. 2001), low-income Catholics who matured after Vatican II are alienated by the hierarchical and authoritative nature of the Catholic Church and no longer view the Church as essential. We cannot adjudicate these interpretations with the evidence at hand.

The results from our analyses raise several other questions we are unable to address here. Future research can build on them, however, by examining how the material costs of religious participation translate into social costs, by determining if low-income, white Catholics find other religious or social outlets to replace their reduced levels of church participation and by exploring reasons why low-income, white Catholics are so disinclined to attend church. Further clarification of the role ethnicity plays in the relationship between income and religious participation seems warranted, and more extensive measures of social integration variation in Latino and poor white Catholic communities can be expected to increase our understanding. As the analysis of religious beliefs and personal religiosity demonstrates, a multidimensional approach to religion is especially pertinent when examining the religion of low-income Americans because they often emphasize different aspects of religion than do other Americans (Demerath 1965; Kenney, Cromwell and Vaughan 1977). 
Finally, the institutional structure, demography and operation of the religious organization, itself, needs a closer examination. How is the Catholic Church positioning itself in the religious marketplace? Have the strategies for securing and retaining adherents been changing? Has the U.S. Catholic Church been, consciously or not, pursuing a policy emphasizing the suburban niche, and, therefore, primarily those Catholics who live in financially better-off locations? This is, after all, a two-sided question: who are the primary target populations of the institution and how do people, especially low-income people, react to opportunities the Church provides them to participate? From the more applied side of sociology, it is important to understand how religious organizations might better appeal to low-income constituents. Not only are churches not fully serving as a religious resource for the lower classes, but they do not always challenge "the exclusive conceptions of community" that can develop in congregations lacking class diversity (Smith 2001:312). Unfortunately, middle-class parishioners may even use religious congregations to shelter themselves from the problems associated with the poor (Weissbourd 2000). We conclude with this question: what can the Catholic Church do to offer low-income, white Catholics religious activities and experiences that mitigate the costs of participation and attract them back to Mass?

\section{Notes}

1. Although Catholics are increasingly likely lately to switch religions, they remain considerably less likely than Protestants to switch to another religion. For example, according to the U.S. Religious Landscape Survey (Lugo et al. 2008), 35 percent of Protestants and 18 percent of Catholics switched from their childhood religion to another religion.

2. Age is coded as years of age. Following Hout and Greeley's (1987) analysis of church attendance, we tested for curvilinear effects of age. Age-square (but no higher order effect) has a meaningful effect on white Catholics' church attendance, but not on Latino/non-white Catholics' church attendance. To adjust for problems of multicollinearity between age and age-square, age is centered on the mean of age. Sex is measured with a dummy variable for female respondents. Marital status is measured with a dummy variable for currently married respondents. Having "children in the home" is a dummy variable for respondents who report the presence of children 17 years old or younger in their homes. Urban location is a dummy variable for respondents who live in one of the 100 largest SMSAs in the country. East is a dummy variable for respondents who live in the New England, Middle Atlantic, East North Central, West North Central, South Atlantic and East South Central census regions (as opposed to West South Central, Mountain and Pacific). This coding reflects the historically high levels of Catholic religious participation in the East and the Midwest (Greeley and Rossi 1964) and the distribution of Latinos across the United States (U.S. Census Bureau 2000b). Education is coded as the number of years of education. 
3. Identical models limited to Latino Catholics (instead of all Latino/non-white Catholics) produce similar but even less robust results as those in Models 1-F and $1-G$.

4. The organizational membership variable is the sum of the number of different types of non-church organizations the respondents belong to (fraternal, service, veteran, political, labor union, sports, youth, school service, hobby, school fraternity, nationality, farm, literary or art, professional and other). Among white Catholics, 34 percent report zero non-church memberships, 27 percent report one membership, 17 percent report two memberships, 11 percent report three memberships, 6 percent report four memberships, 3 percent report five memberships, 2 percent report six memberships and 2 percent report more than six memberships.

5. Fifty percent of white Catholics report working fulltime.

6. Among white Catholics, 40 percent report that their financial situation has gotten better, 21 percent report that their financial situation has gotten worse and 39 percent report that their financial situation stayed the same.

7. Among white Catholics, 3 percent view their family income as far below average, 18 percent as below average, 55 percent as average, 22 percent as above average and 2 percent as far above average. While view of income is correlated with income (.47 correlation between unlogged real income and view of income for white Catholics), there is considerable income variation within each response category of the view of income variable. For example, 15 percent of white Catholics who view their income as far below average have family incomes over $\$ 69,000$ and 15 percent of white Catholics who view their income as far above average have family incomes below $\$ 32,000$.

8. Forty-two percent of white Catholics report the presence of children 17 years or younger in their home.

9. There is no random cohort intercept in Model 2-D. Instead of a random cohort effect, cohort dummy variables (fixed-effects) measure cohort variation.

10. Respondents were asked, "To what extent do you consider yourself a religious person?" The response options are not religious at all, slightly religious, moderately religious and very religious. Respondents were also asked how often the following statement is true: "I find strength and comfort in my religion." The response options are never/almost never, once in a while, some days, most days, every day and many times a day.

11. The dichotomous afterlife question, "Do you believe there is a life after death," has response categories of no and yes. The view of the Bible variable is based on the following question: "Which of these statements comes closest to describing your feelings about the Bible? The Bible is the actual word of God and is to be taken literally, word for word. The Bible is the inspired word of God but not everything in it should be taken literally, word for word. The Bible is an ancient book of fables, legends, history and moral precepts recorded by men." 
12. A variable indicating foreign-born respondents is included in the Latino-only models to control for potentially spurious results. Forty percent of Latino Americans were not born in the United States (Malone et al. 2003). Similarly, 47 percent of Latino Catholics in GSS samples are not native to the United States. Nativity is also significantly correlated with two of the four measures of social integration/isolation employed with the Latino sample: the correlation for urbanity and foreign born is .19 and the correlation for geographic mobility and foreign born is .35 .

13. Fifty-seven percent of Latinos work fulltime. Among Latinos, 56 percent have no non-church organizational memberships, 19 percent have one membership, 11 percent have two memberships, 5 percent have three memberships, 7 percent have four memberships and 4 percent have five or more memberships.

14. The GSS has a measure of respondents' estimates of the proportion of Hispanics in their communities. Unfortunately, after deleting cases with missing data on control variables, only 43 Latino Catholics have valid responses on this measure.

15. Fifty-nine percent of Latinos report living in a different city, town or county than they lived in when they were 16 years old.

16. Identical analyses limited to white and Latino Catholics show nearly identical results. We include non-white, non-Latino Catholics in the correlations due to the small sample size.

17. Importance of career and work ranges from unimportant (1) to very important (7). Importance of financial security ranges from not important at all (1) to one of the most important values held (5). Need ambition to get ahead, need to work hard to get ahead, need to know people to get ahead and need to be right religion to get ahead are coded as follows: not important at all, not very important, fairly important, very important and essential.

\section{References}

Alston, Jon P., and William Alex Mclntosh. 1979. "An Assessment of the Determinants of Religious Participation." Sociological Quarterly 20(1):49-62.

Baker, David P., and Cornelius Riordan. 1998. "The 'Eliting' of the Common American Catholic School and the National Education Crisis." Phi Delta Kaplan 80(1):16-23.

Blau, Peter M. 1956. "Social Mobility and Interpersonal Relations." American Sociological Review 21(3):290-95.

Carlos, Serge. 1970. "Religious Participation and the Urban-Suburban Continuum." The American Journal of Sociology 75(5):742-59.

Chaves, Mark. 2004. Congregations in America. Harvard University Press.

Cutler, Stephen J., and Jon Hendricks. 2000. "Age Differences in Voluntary Association Memberships: Fact of Artifact." Journal of Gerontology 55B(2):S98-S107. 
D'Antonio, William V., James D. Davidson, Dean R. Hoge and Ruth A. Wallace. 1996. Laity: American and Catholic: Transforming the Church. Sheed \& Ward.

Davidson, James D., and Andrea S. Williams. 1997. "Megatrends in 20 $0^{\text {th }}$-century American Catholicism." Social Compass 44(4):507-27.

Davidson, James D., Andrea S. Williams, Richard L. Lamanna, Jan Stenftenagel, Kathleen Maas Weigert, William J. Whalen and Patricia Witburg. 1997. "The Search for Common Ground: What Unites and Divides Catholic Americans." Our Sunday Visitor.

Davis, James A., Tom W. Smith and Peter V. Marsden. 2007. GENERAL SOCIAL SURVEYS, 1972-2006 [CUMULATIVE FILE] [computer File]. ICPSR04697-v1. Chicago, IL: National Opinion Research Center [producer]. Storrs, CT: Roper Center for Public Opinion Research, University of Connecticut/Ann Arbor, MI: Inter-university Consortium for Political and Social Research [distributors], 2007-05-31.

Demerath III, N.J. 1965. Social Class in American Protestantism. Rand McNally.

Dougherty, Kevin D. 2003. "How Monochromatic is Church Membership? RacialEthnic Diversity in Religious Communities." Sociology of Religion 64(1):65-85.

Durkheim, Emile. 1951. Suicide: A Study in Sociology. John A. Spaulding and George Simpson, translators. The Free Press.

Ellison, Christopher G. 1995. "Rational Choice Explanations of Individual Religious Behavior: Notes on the Problem of Social Embeddedness." Journal for the Scientific Study of Religion 34(1):89-97.

Ellison, Christopher G., and Darren E. Sherkat. 1995. "The 'Semi-involuntary Institution' Revisited: Regional Variations in Church Participation among Black Americans." Social Forces 73(4):1415-37.

Estus, Charles W., and Michael A. Overington. 1970. "The Meaning and End of Religiosity." The American Journal of Sociology 75(5):760-78.

Finke, Roger, and Rodney Stark. 1992. The Churching of America, 1776-1990. Rutgers University Press.

Firebaugh, Glenn, and Brian Harley. 1991. "Trends in U.S. Church Attendance: Secularization and Revival, or Merely Lifecycle Effects?" Journal for the Scientific Study of Religion 30(4):487-500.

Francis, Sally K. 1992. "Effect of Perceived Clothing Deprivation on High School Students' Social Participation." Clothing and Textile Research Journal 10(2):29-33.

Fukuyama, Yoshio. 1961. "The Major Dimensions of Church Membership." Review of Religious Research 2(4):154-61. 
Goode, Erich. 1966. "Social Class and Church Participation." American Journal of Sociology 72(1):102-11.

Greeley, Andrew M., and Peter H. Rossi. 1964. "Correlates of Parochial School Attendance." The School Review 72(1):52-73.

Guest, Avery M., and Keith R. Stamm. 1993. "Paths of Community Integration." The Sociological Quarterly 34(4):581-95.

Haynie, Dana L., Scott J. South and Sunita Bose. 2006. "Residential Mobility and Attempted Suicide among Adolescents: An Individual-Level Analysis." The Sociological Quarterly 47(4):693-721.

Herberg, Will. 1960. Protestant - Catholic - Jew: an Essay in American Religious Sociology. Anchor.

Hoge, Dean R., and Jackson W. Carroll. 1978. "Determinants of Commitment and Participation in Suburban Protestant Churches." Journal for the Scientific Study of Religion 17(2):107-27.

Hoge, Dean R., William D. Dinges, Mary Johnson and Juan L. Gonzales, Jr. 2001. Young Adult Catholics: Religion in the Culture of Choice. University of Notre Dame Press.

Hoge, Dean R., and David A. Roozen. 1979. "Influencing Church Commitment." Pp. 42-68. Understanding Church Growth and Decline: 1950-1978. Dean R. Hoge and David A. Roozen, editors. Pilgrim Press.

House, James S., Debra Umberson and Karl Richard Landis. 1988. "Structures and Processes of Social Support." Annual Review of Sociology 14:293-318.

Hout, Michael, and Andrew M. Greeley. 1987. "The Center Doesn't Hold: Church Attendance in the United States, 1940-1984." American Sociological Review 52(3):325-45.

Hunt, Mathew O., and Larry L. Hunt. 2000. "Regional Religions?: Extending the 'Semi-Involuntary' Thesis of African-American Religious Participation." Sociological Forum 15(4):569-94.

Ihinger-Tallman, Marilyn, and Kay Pasley. 1986. "Remarriage and Integration within the Community." Journal of Marriage and the Family 48(2):395-405.

Keister, Lisa A. 2007. "Upward Wealth Mobility: Exploring the Roman Catholic Advantage." Social Forces 85(3):1195-1225.

Kenney, Bradford P., Ronald E. Cromwell and C. Edwin Vaughan. 1977. "Identifying the Socio-Contextual Forms of Religiosity among Urban Ethnic Minority Groups." Journal for the Scientific Study of Religion 16(3):237-44.

Kessin, Kenneth. 1971. "Social and Psychological Consequences of Intergenerational Occupational Mobility." The American Journal of Sociology 77(1):1-18. 
Knoke, David, and Randall Thomson. 1977. "Voluntary Association Membership Trends and the Family Life Cycle." Social Forces 56(1):48-65.

Krueger, Patrick M., Richard G. Rogers, Robert A. Hummer, Felicia B. LeClere and Stephanie A. Bond Huie. 2003. "Socioeconomic Status and Age: The Effect of Income Sources and Portfolios on U.S. Adult Mortality." Sociological Forum 18(3):465-82.

Lee, Richard R. 1992. "Religious Practice as Social Exchange: An Explanation of the Empirical Findings." Sociological Analysis 53(1):1-35.

Lenski, Gerhard. 1963. The Religious Factor: A Sociologist's Inquiry. Anchor Books.

Levitt, Peggy. 1998. "Local-level Global Religion: The Case of U.S.-Dominican Migration." Journal for the Scientific Study of Religion 37(1):74-89.

Lipford, Jody W., and Robert D. Tollison. 2003. "Religious Participation and Income." Journal of Economic Behavior \& Organization 51(2):249-60.

Liu, William T. 1960. "The Marginal Catholics in the South: A Revision of Concepts." The American Journal of Sociology 65(4):383-90.

Logan, John R., Brian J. Stults and Reynolds Farley. 2004. "Segregation of Minorities in the Metropolis: Two Decades of Change." Demography 41(1):1-22.

Lugo, Luis, Sandra Stencel, John Green, Gregory Smith, Dan Cox, Allison Pond, Tracy Miller, Elizabeth Podrebarac, Michelle Ralston, Andrew Kohut, Paul Taylor and Scott Keeter. 2008. U.S. Religious Landscape Survey. Pew Research Center.

Malone, Nolan, Kaari F. Baluja, Joseph M. Costanzo and Cynthia J. Davis. 2003. "The Foreign-Born Population: 2000." Census 2000 Brief (C2KBR-34), December. Washington, DC: U.S. Census Bureau.

McCloud, Sean. 2007. "Putting Some Class into Religious Studies: Resurrecting an Important Concept." Journal of the American Academy of Religion 75(4):840-62.

McGavran, Donald A. 1980. Understanding Church Growth. William B. Eerdmans Publishing Company.

Mueller, Charles W., and Weldon T. Johnson. 1975. "Socioeconomic Status and Religious Participation." American Sociological Review 40(6):785-800.

Nash, Dennison, and Peter Berger. 1962. "The Child, the Family, and the 'Religious Revival' in Suburbia." Journal for the Scientific Study of Religion 2(1):85-93.

Niebuhr, H. Richard. 1929. The Social Sources of Denominationalism. Henry Holt.

Odem, Mary E. 2004. "Our Lady of Guadalupe in the New South: Latino Immigrants and the Politics of Integration in the Catholic Church." Journal of American Ethnic History 24(1):26-57. 
Orsi, Robert A. 1985. The Madonna of $115^{\text {th }}$ Street: Faith and Community in Italian Harlem. Yale University Press.

Phillips, Tommy M., and Joe F. Pittman. 2003. "Identity Processes in Poor Adolescents: Exploring the Linkages between Economic Disadvantage and the Primary Task of Adolescence." Identity: An International Journal of Theory and Research 3(2):115-29.

Pollock III, Philip H. 1982. "Organizations and Alienation: The Mediation Hypothesis Revisited." Sociological Quarterly 23(2):143-55.

Putnam, Robert D. 1995. "Tuning In, Tuning Out: The Strange Disappearance of Social Capital in America." PS: Political Science and Politics 28(4):664-83.

Pyle, Ralph E. 2006. "Trends in Religious Stratification: Have Religious Group Socioeconomic Distinctions Declined in Recent Decades?" Sociology of Religion 67(1):61-79.

Rotolo, Thomas. 2000. "A Time to Join, A Time to Quit: The Influence of Life Cycle Transitions on Voluntary Association Membership." Social Forces 78(3):1133-61.

Sakalas, Joan. 1999. "Face to Face: Transforming Faith-Based Outreach." Pp. 201-12. Welfare Policy: Feminist Critiques. Elizabeth M. Bounds, Pamela K. Brubaker and Mary E. Hobgood, editors. The Pilgrim Press.

Sandomirsky, Sharon, and John Wilson. 1990. "Processes of Disaffiliation: Religious Mobility among Men and Women." Social Forces 68(4):1211-29.

Scammon, Richard M. 1967. "Electoral Participation." Annals of the American Academy of Political and Social Science 371(1):59-71.

Schwadel, Philip. 2005. "Neighbors in the Pews: Social Status and Racial Diversity in Christian Congregations." Paper presented at the annual meeting of the Society for the Scientific Study of Religion, Rochester, NY, Nov. 4.

Shaw, Stephen J. 1991. The Catholic Parish as a Way-Station of Ethnicity and Americanization: Chicago's Germans and Italians, 1903-1939. Carlson Publishing Inc.

Sherkat, Darren, and John Wilson. 1995. "Preferences, Constraints, and Choices in Religious Markets: An Examination of Religious Switching and Apostasy." Social Forces 73(3):993-1026.

Smith, Christian, and Robert Faris. 2005. "Socioeconomic Inequality in the American Religious System: An Update and Assessment." Journal for the Scientific Study of Religion 44(1):95-104.

Smith, Drew. R. 2001. "Churches and the Urban Poor: Interaction and Social Distance." Sociology of Religion 62(3):301-13. 
Stark, Rodney. 1972. "The Economics of Piety: Religious Commitment and Social Class." Pp. 483-503. Issues in Social Inequality. Gerald W. Thielbar and Saul D. Feldman, editors. Little, Brown \& Company.

Stark, Rodney, and Roger Finke. 2000. Acts of Faith: Explaining the Human Side of Religion. University of California Press.

Stern, Samuel E., and Francis P. Noe. 1973. "Affiliation-Participation in Voluntary Associations: A Factor in Organized Leisure Activity." Sociology and Social Research 57(4):473-81.

Stump, Roger W. 1984. "Regional Migration and Religious Commitment in the United States." Journal for the Scientific Study of Religion 23(3):293-303.

Suro, Roberto, Gabriel Escobar, Gretchen Livingston, Shirin Hakimzadeh, Luis Lugo, Sandra Stencel, John C. Green, Gregory A. Smith, Dan Cox and Sahar Chaudhry. 2007. Changing Faiths: Latinos and the Transformation of American Religion. Pew Research Center.

U.S. Census Bureau. 2000a. "Table 20.1 Population by MetropolitanNonmetropolitan Residence, Sex, Hispanic Origin, and Race, with Percent Distribution by Metropolitan-Nonmetropolitan Residence." Current Population Survey, March. Available at: http://www.census.gov/population/socdemo/ hispanic/p20-535/tab20-1.txt.

U.S. Census Bureau. 2000b. “Census 2000 PHC-T-10. Hispanic or Latino Origin for the United States, Regions, Divisions, States, and for Puerto Rico." Tables 1-D1 through 1-D9. Available at: http://www.census.gov/population/cen2000/ phc-t10/phc-t-10.pdf.

Vidich, Arthur J., and Joseph Bensman. 1958. Small Town in Mass Society. Princeton University Press.

Weber, Max. 1946. "The Protestant Sects and the Spirit of Capitalism." Pp. 302-22. From Max Weber: Essays in Sociology. H.H. Gerth and C. Wright Mills, editors. Oxford University Press.

Weissbourd, Richard. 2000. "Beyond 'Villages': New Community Building Strategies For Disadvantage Families." Pp. 219-37. Who Will Provide: The Changing Role of Religion in American Social Welfare. Mary Jo Bane, Brent Coffin and Ronald Thiemann, editors. Westview Press.

Welch, Michael R., and John Baltzell. 1984. "Geographic Mobility, Social Integration, and Church Attendance." Journal for the Scientific Study of Religion 23(1):75-91.

Welniak, Ed, and Kirby Posey. 2005. "Household Income: 1999." Census 2000 Brief (C2KBR-36), June. U.S. Census Bureau. 


\section{0 - Social Forces 87(4)}

Yang, Yang, and Kenneth C. Land. 2006. "A Mixed-Models Approach to the Age-Period-Cohort Analysis of Repeated Cross-Section Surveys, with an Application to Data on Trends in Verbal Test Scores." Sociological Methodology 36(1):75-97. 